\title{
FITNESS OF AIR QUALITY MEASUREMENT EQUIPMENT FOR REAL-TIME AEROBIOLOGICAL MONITORING: CASE STUDY FROM RĪGA
}

\section{Gaisa kvalitātes novērtēšanas aprīkojuma pielietojums reālā laika aerobioloǵiskajā monitoringā: Rīgas piemērs}

\author{
Olga Ritenberga \\ University of Latvia, Faculty of Geography and Earth Sciences \\ olga.ritenberga@lu.Iv
}

\begin{abstract}
There are about 300 aerobiological monitoring stations in Europe, providing regular observational data on pollen and spore concentration in the air. The data is available with a delay of 12 weeks or even more, which makes direct use for model-based forecasting immensely problematic. Automatic real-time pollen monitors are too expensive for massive deployment. Therefore, the primary attention is presently being put either to forecasting models that do not use observations in daily routine or to alternative ways for near real-time equipment for pollen monitoring. One of the solutions is an adaptation of existing air quality equipment for the needs of aerobiological monitoring. This study performs an analysis of the GRIMM monitoring station capability for the afore-mentioned purposes.
\end{abstract}

Keywords: aerobiology, air quality, alternative aerobiological monitoring, total real-time pollen counts

\section{Introduction}

The importance of aerobiological research follows at least two main lines human health issues - through pollen allergy (polinosis) (Newson et al. 2014; Ring et al. 2012), as well as phenology and agriculture as studies of the timing of phenological phases and the productivity of plants (Aguilera and Ruiz-Valenzuela 2014; Orlandi et al. 2005). Both lines support the necessity of aerobiological forecasts of pollen and related processes including the start/end of flowering (Ritenberga et al. 2016), annual pollen productivity of plants (Ritenberga et al. 2018), and the interseasonal fluctuation of pollen depending on meteorological and environmental conditions. Precise forecasting models require data as fresh as possible because one of the most accurate air quality forecasts is the persistence forecast - which states that yesterday's actual situation is the best forecast for today (Sofiev et al. 2017).

The dense network of manual aerobiological sites (Figure 1) requires a regular, time-consuming effort on the job as all the samples are counted manually using microscopes. Automatic real-time pollen monitors, capable of providing necessary aerobiological data on time, are too expensive for massive deployment. Therefore, the primary attention currently is put to forecasting models that do not use observations in daily routine, being only calibrated and evaluated against them in an offline mode. Automatic pollen monitoring trials from different producers have begun at several European monitoring stations (Scheifinger et al. 2013), but for the time being, its accuracy is far behind the manual monitoring accuracy (Crouzy et al. 2016; Šauliene 
et al. 2019). Scientists are continuously looking for automatization of the aerobiological monitoring and data collection.

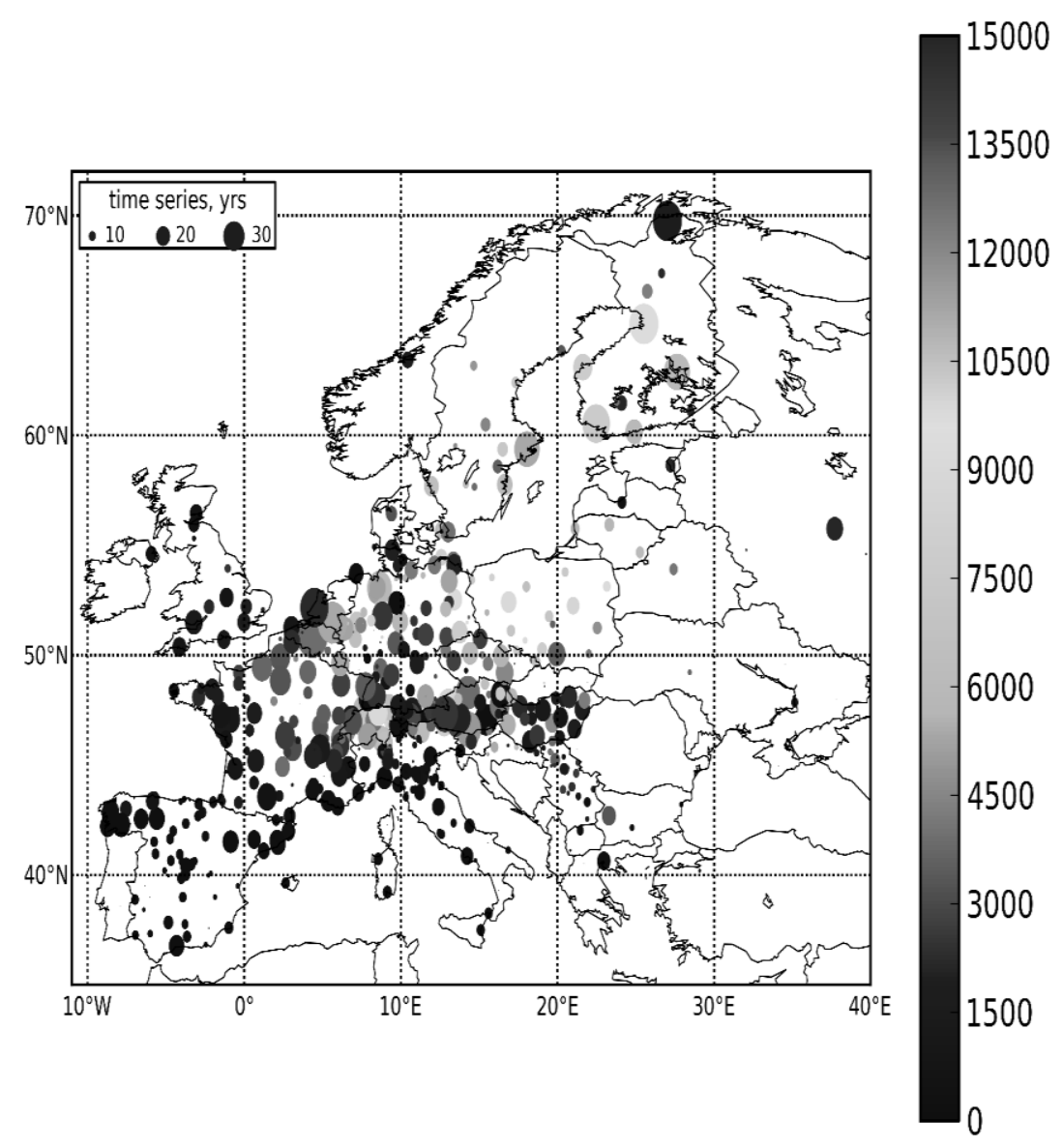

Figure 1. The density of European Aero-allergen Network monitoring stations (Ritenberga 2017)

This present study aims to evaluate the potential of the GRIMM air quality monitoring station for aerobiological research during the start of the pollen season when only several (1 to 3 ) pollen species are present in the air and when is possible to separate these by seasonal timing of plant flowering.

\section{Data and Methods}

Monitoring of air pollution was performed in the central part of Rīga city (N56 57'02', E2406' 57''), Latvia. The relative height for data collection is 23 meters agl, and two different samplers were used for air pollution measurements:

- Firstly, aerobiological monitoring was made by using the Hirst type 7-day Burkard pollen-spore trap (Hirst 1954). Data acquisition was carried out by requirements developed by a data quality control group (Galán et al. 2014; Oteros et al. 2013), who formulated the recommendations for monitoring processes and equipment. Seven days are required for data collection and at least one day for the manual microscopic analysis of pollen samples. Pollen recognition and counting procedures were performed at the University of 
Latvia Faculty of Geography and Earth Sciences (UL FGES) Quaternary laboratory using a Primo Star Light Microscope under $\times 400$ magnification and by choosing a vertical counting method - 12 vertical traverses (Carinanos et al. 2000) with the distance of $2 \mathrm{~mm}$, thus, covering a daily sample of $14 \times 48 \mathrm{~mm}$. Later, re-calculation to concentration was performed by using a convertional factor.

- Every single aerosol particle was detected by GRIMM EDM and allocated to a defined particle size based on the intensity of the scattering light signal. This precise and reliable single particle (particulate matter, further PM) count allows for simultaneous measurement of the fractions $\mathrm{PM}_{10}, \mathrm{PM}_{2.5}$, $\mathrm{PM}_{1}$ and also the particle size distribution in 31 size channels. To guarantee the precision of the measurements, and to protect the measuring cell from contamination, the constant 1,2 1/min sample air flow is filtered and brought back into the device as rinsing air. Particulate matter data collected by the pollution monitoring station for the same periods was re-calculated to 2 hours data (because of the minimal step of pollen data) for the year 2014 and daily values for the year 2017.

Filtering of data, normalization and data analysis was performed by using the $\mathrm{R}$ programming tool.

\section{Results}

As GRIMM does not provide exact pollen-sized PM channels, data was merged from size $25 \mu \mathrm{m}$ to $31 \mu \mathrm{m}$ to cover all the possible pollen size range (for hazel, birch, alder). Making data from the above-described devices comparable, normalization was performed by deviation to mean hourly/daily values depending on the year.

It was assumed that moderate wind conditions and even some air turbulence, usually responsible for vertical air flow in an urban environment, is not sufficient to bring heavy, pollen-sized PM at the height of $23 \mathrm{~m}$. Thus, this study explored GRIMM PM output from channel $25-31 \mu \mathrm{m}$ as biological particles, i.e., as pollen.

The analysing period from mid-April to the beginning of June fits in with the birch flowering season in Latvia. The first peak of the data (Figure 2, lower panel) possibly demonstrates the end of the hazel/alder pollen season. Daily data (Figure 2) of pm_Betula-sized_norm and Betula_conc_norm does not display the well-seen relationship, at the same time, higher resolution of the same data (Figure 3) provides additional information on inter-connection of the particles from different devices.

As previously described (Ritenberga et al. 2016; 2017) the substantial role of air temperature (in the timing of birch phenological phases and pollen season start/course/etc.) is confirmed by the current study. Visualisation of the result (Figure 2) confirms the hypothesis of GRIMM measured particles as being pollen because PM is not as sensitive to temperature changes as particles with biological origin. The curve of birch-pollen-sized particles and the birch pollen concentration curve repeats all the peaks from the increase of air temperature. 


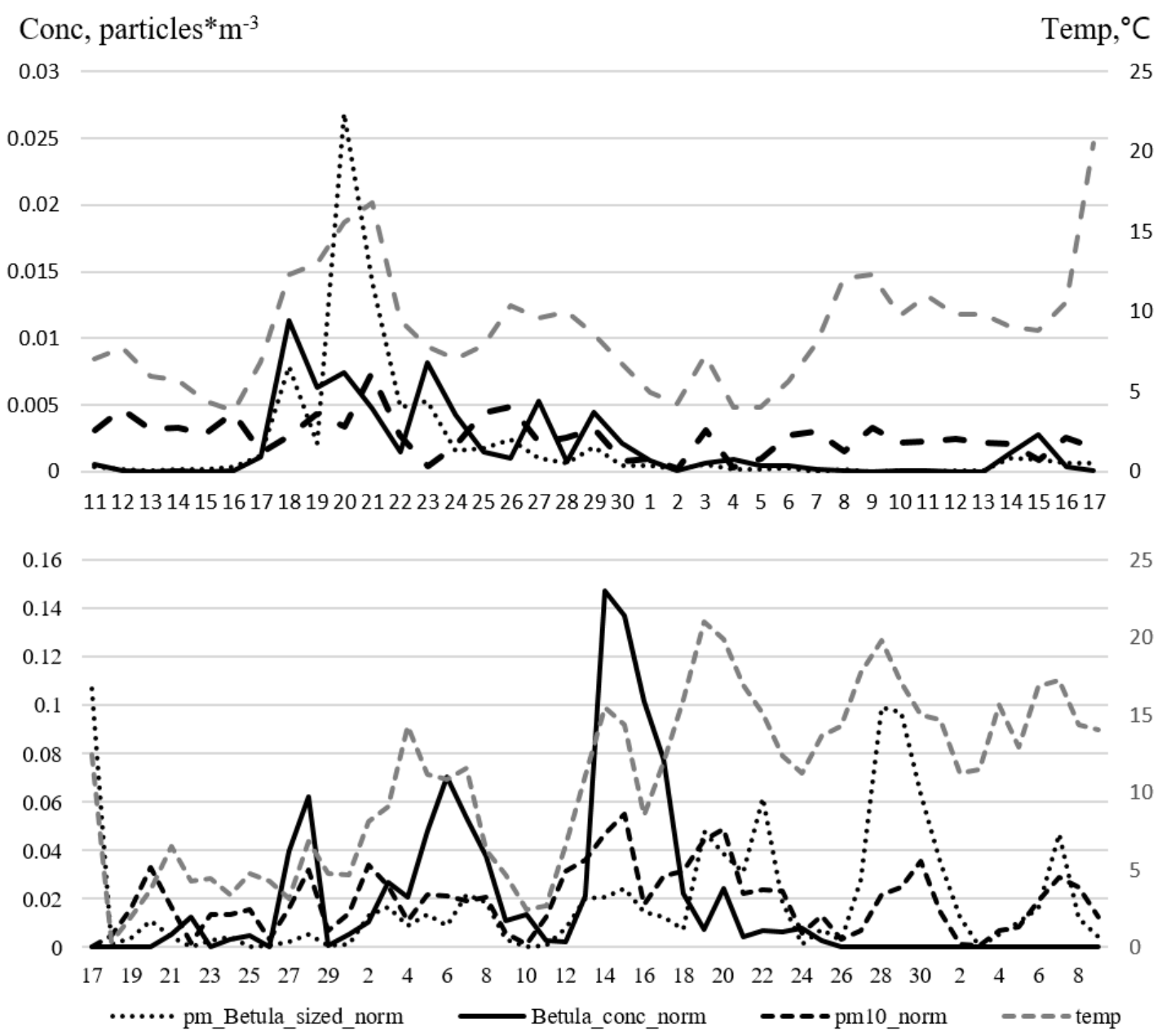

Figure 2. Comparison of the seasonal passage of normalized particle daily concentrations: the example of 2014 (upper panel) and 2017 (lower panel) (author's figure)

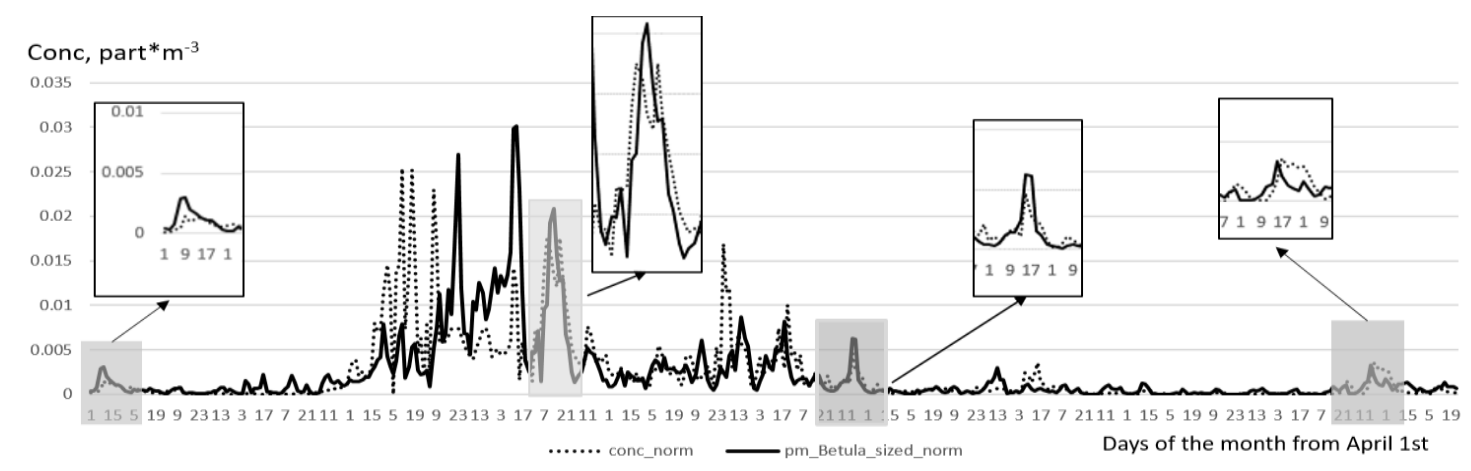

Figure 3. Seasonal variation of air pollution bi-hourly data: the example of 2014 (author's figure)

There is not enough daily data for the reliable performance of the statistical analysis. Correlation analysis was performed only for seasonal bi-hourly data, thus presenting the correlation coefficient $r$ of 0.7-0.85 depending on the analysed period of both years. 
However, GRIMM is designed for particulate matter measurements, and the exclusion of possible presence of heavy dust particles allows us to admit the use of the device for total high-resolution (i.e., hourly or bi-hourly) pollen measurements. Figure 3 demonstrates a noticeable coincidence of values - several examples zoomed. The patterns of both curves are similar despite the significant difference in absolute values at the beginning of the season which was probably caused by the presence of alder and hazel pollen in the air.

Normalization of the data doesn't allow us to evaluate absolute difference and an insufficient amount of data doesn't allow us to define calibration criteria for both devices. So far, the only possibility for absolute value calculation seems to be through the seasonal pollen index as described (Ritenberga et al. 2018).

Diurnal mean variation was observed in data from both devices. It follows diurnal temperature changes. Figure 4 shows a smooth tracking of the temperature curve by the output from the GRIMM device, whereas Burkard is a much sharper device with a bigger time-step. Resolution of GRIMM allows us to receive ideal diurnal pollen curve (Kasprzyk et al. 2001).

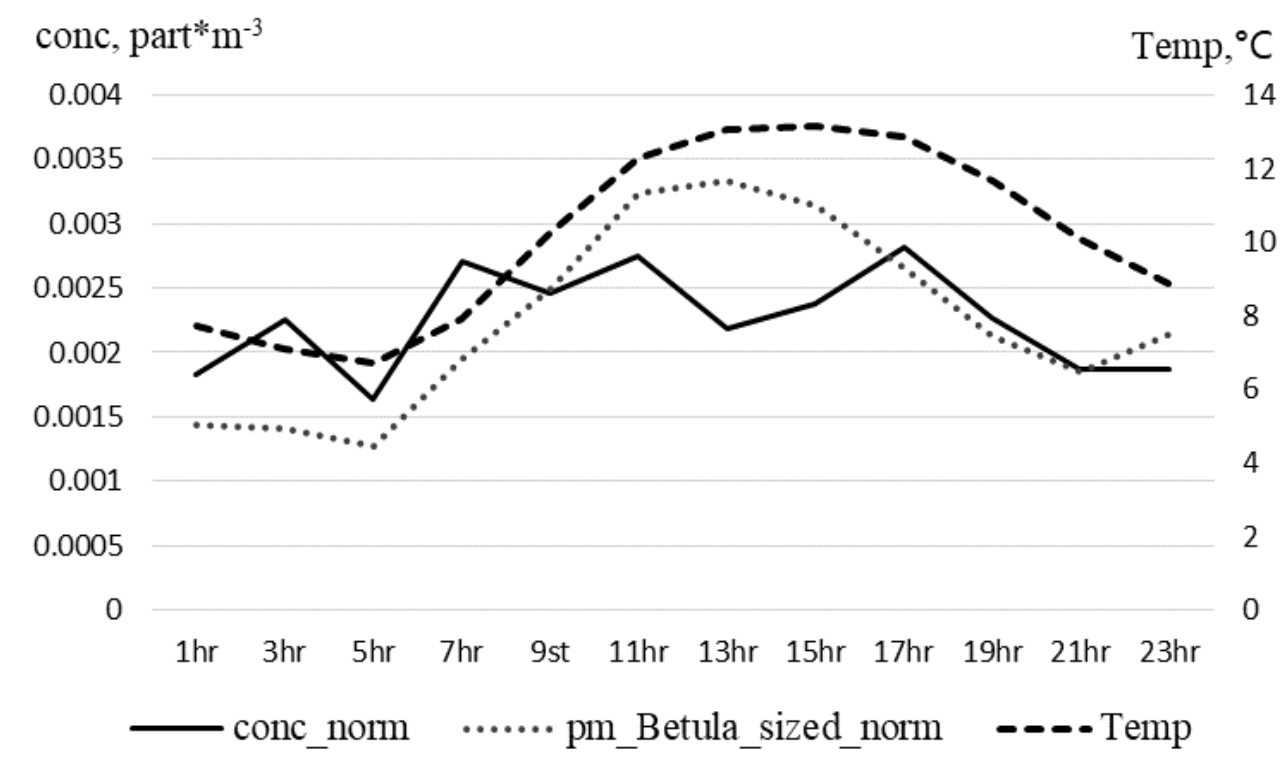

Figure 4. Mean hour-to-hour variation of air pollution: the example of 2014 (author's figure)

\section{Conclusion.}

The hypothesis on the fitness of air quality monitoring stations for pollen observation is partly confirmed - it is possible to use GRIMM for recording total pollen counts and in the case of:

- description of calibration coefficient for both devices as well as

- proper evaluation of wind speed impact on the vertical profile of particulate matter - here, the difference of pollen and PM mass allows us to measure big aerosols $(\mathrm{pm}>25 \mu \mathrm{m})$ as pollen at the height of $25-30 \mathrm{~m}$ agl. 
Further studies should be performed to clarify the above-mentioned objectives. The accuracy of GRIMM for pollen monitoring depends on the timing of the measurements. The long-year mean and seasonal variation of pollen spectra helps us to better define the proper time for single taxon monitoring, as distinguishing by pollen type is not possible using the mentioned technique.

\section{Acknowledgement}

This study was performed within the scope of the project of EC ERDF and PostDoc Latvia N ${ }^{\circ}$ 1.1.1.2/VIAA/2/18/283 "Development of Pollen Data Fusion and Assimilation: Real-time Monitoring and Modelling for Public Health PREMIuM."

\section{Kopsavilkums}

Eiropā ir ap 300 aerobioloǵisko monitoringa vietu, kas regulāri veic putekšṇu un sporu mērījumus gaisā. N̦emot vērā izmantoto mērierīču specifikāciju, dati ir pieejami ar 1-2 nedēḷ nobīdi, kas ietekmē putekšṇu koncentrācijas prognožu precizitāti. Automātisko reālā laika putekšņu monitoru iegāde un kalibrācija prasa lielus finanšu ieguldījumus. Kā iespējamo risinājumu var minēt prognostisko modeḷu uzbūvi, kas gandrīz neprasa novērojumu datus, vai esošo mērierīču pielāgošanu putekšņu un sporu reālā laika mērījumiem. Viens no variantiem ir gaisa kvalitātes mērǐsanas aprīkojuma izmantošana aerobioloǵisko mērḳu sasniegšanai. Šis pētijums izvērtē GRIMM gaisa kvalitātes monitoringa stacijas datu izmantošanu, lai mērītu putekšṇu koncentrāciju noteiktā laika periodā.

\section{References}

Aguilera, F. and Ruiz-Valenzuela, L. (2014). Forecasting olive crop yields based on long-term aerobiological data series and bioclimatic conditions for the southern Iberian Peninsula. Spanish Journal of Agricultural Research, 12, 215-224.

Carinanos, P., Emberlin, J., Galan, C. and Dominguez-Vilches, E. (2000). Comparison of two pollen counting methods of slides from a hirst type volumetric trap. Aerobiologia (Bologna), 16, 339-346.

Crouzy, B., Stella, M., Konzelmann, T., Calpini, B. and Clot, B. (2016). All-optical automatic pollen identification: Towards an operational system. Atmospheric Environment, 140, 202-212.

Cunha, M. and Ribeiro, H. (2015). Pollen-based predictive modelling of wine production: Application to an arid region. European Journal of Agronomy, 73, $42-54$.

Galán, C., Smith, M., Thibaudon, M., Frenguelli, G., Oteros, J., Gehrig, R., Berger, U., Clot, B. and Brandao, R. (2014). Pollen monitoring: minimum requirements and reproducibility of analysis. Aerobiologia (Bologna). 30, 385-395.

Hirst, J.M. (1954). An automatic volumetric spore trap. Annals of Applied Biology, 39, 257-265.

Kasprzyk, I., Harmata, K., Myszkowska, D., Stach, A. and Stepalska, D. (2001). Diurnal variation of chosen airborne pollen at five sites in Poland. Spore, 327-345.

Newson, R.B., van Ree, R., Forsberg, B., Janson, C., Lötvall, J., Dahlén, S.-E., Toskala, E.M., Baelum, J., Brożek, G.M., Kasper, L., Kowalski, M.L., Howarth, P.H., Fokkens, W.J., Bachert, C., Keil, T., Krämer, U., Bislimovska, J., Gjomarkaj, M., Loureiro, C., Burney, P.G.J. and Jarvis, D. (2014). Geographical variation in the prevalence of sensitization to common aeroallergens in adults: the $\mathrm{GA}(2)$ LEN survey. Allergy.

Orlandi, F., Romano, B. and Fornaciari, M. (2005). Relationship between pollen emission and fruit production in olive (Olea europaea L.). Grana, 44, 98-103.

Oteros, J., Galan, C., Alcazar, P. and Dominguez-Vilches, E. (2013). Quality control in biomonitoring networks, Spanish Aerobiology Network. Science of the Total Environment, 443, 559-565.

Ring, J., Akdis, C., Behrendt, H., Lauener, R.P., Schäppi, G., Akdis, M., Ammann, W., de Beaumont, O., Bieber, T., Bienenstock, J., Blaser, K., Bochner, B., Bousquet, J., Crameri, R., Custovic, A., Czerkinsky, C., Darsow, U., Denburg, J., Drazen, J., de Villiers, E.M., Fire, A., Galli, S., Haahtela, T., 
zur Hausen, H., Hildemann, S., Holgate, S., Holt, P., Jakob, T., Jung, A., Kemeny, M., Koren, H., Leung, D., Lockey, R., Marone, G., Mempel, M., Menné, B., Menz, G., Mueller, U., von Mutius, E., Ollert, M., O’Mahony, L., Pawankar, R., Renz, H., Platts-Mills, T., Roduit, C., Schmidt-Weber, C., Traidl-Hoffmann, C., Wahn, U. and Rietschel, E. (2012). Davos declaration: allergy as a global problem. Allergy, 67, 141143.

Ritenberga, O. (2017). Forecasting the geospatial and temporal patterns of pollen season in Europe using statistical and deterministic modelling. Riga: University of Latvia. https://dspace.lu.lv/dspace/handle/7/37532

Ritenberga, O., Sofiev, M., Kirillova, V., Kalnina, L. and Genikhovich, E. (2016). Statistical modelling of non-stationary processes of atmospheric pollution from natural sources: Example of birch pollen. Agricultural and Forest Meteorology, 226-227.

Ritenberga, O., Sofiev, M., Siljamo, P., Saarto, A., Dahl, A., Ekebom, A., Sauliene, I., Shalaboda, V., Severova, E., Hoebeke, L., Ramfjord, H. (2018). A statistical model for predicting the inter-annual variability of birch pollen abundance in Northern and North-Eastern Europe. Science of the Total Environment, 615.

Šauliene, I., Šukiene, L., Daunys, G., Valiulis, G., Vaitkevičius, L., Matavulj, P., Brad, S., Panic, M., Sikoparija, B., Clot, B., Crouzy, B., Sofiev, M. (2019). Automatic pollen recognition with the Rapid-E particle counter: the first-level procedure, expercience and next steps (under review). Atmospheric Measurement Techniques.

Scheifinger, H., Belmonte, J., Buters, J., Celenk, S., Damialis, A., Dechamp, C., Garcia-Mozo, H., Gehrig, R., Grewling, L., Halley, J.M., Hogda, K.-A., Jager, S., Karatzas, K., Karlsen, S.-R., Koch, E., Pauling, A., Peel, R., Sikoparija, B., Smith, M., Galan-Soldevilla, C., Thibaudon, M., Vokou, D. and de Weger, L. (2013). Monitoring, modelling and forecasting of the pollen season. In: Sofiev, M. and Bergmann, K.-C. (eds.) Allergenic Pollen. 247.

Sofiev, M., Ritenberga, O., Albertini, R., Arteta, J. and Belmonte, J. (2017). Multi - model ensemble simulations of olive pollen distribution in Europe in 2014. 1-32.

\title{
LANDSCAPE OF SEMI-WILD LARGE HERBIVORES IN THE SPECIALLY PROTECTED NATURE TERRITORIES OF LATVIA
}

\section{Lielie pussavvaḷas zālēdāji īpaši aizsargājamās dabas teritorijās Latvijā}

\author{
Agnese Reķe, Anita Zariņa, Solvita Rūsiña \\ University of Latvia, Faculty of Geography and Earth Sciences \\ agnese.reke@gmail.com
}

\begin{abstract}
Semi-wild large herbivores have been present in the Latvian landscape now for just on 20 years. Nevertheless, the available information about the already implemented introduction projects is scattered and fragmentary. The aim of this paper is to outline and discuss the landscape of semi-wild animal grazing projects in the specially protected nature territories (SPNT) throughout Latvia, focusing on the project implementation contexts, locational factors and current management issues. The results of this study show that grazing areas of semi-wild herbivores are located mainly in nature parks and nature reserves. The typical location for the establishment of a grazing site is a former agricultural land area that has been abandoned by its previous users due to unsuitable conditions for profitable agricultural activity and which is located close to a natural waterbody. The main goal for all of the analyzed introduction projects was the restoration and protection of open landscape and grassland habitats. According to the research results, at
\end{abstract}

